\title{
THE STATESMAN'S YEAR-BOOK
}

1988-1989 
Man hat behauptet, die Welt werde durch Zahlen regiert: das aber weiss ich, dass die Zahlen uns belehren, ob sie gut oder schlecht regiert werde.

GOETHE

\section{Editors}

Frederick Martin

Sir John Scott-Keltie

Mortimer Epstein

S.H. Steinberg

John Paxton
$1864-1883$

$1883-1926$

$1911 / 27-1946$

1946-1969

1963/69- 


\section{THE \\ STATESMAN'S \\ YEAR-BOOK}

STATISTICAL AND HISTORICAL ANNUAL OF THE STATES OF THE WORLD

FOR THE YEAR

1988-1989

EDITED BY

JOHN PAXTON

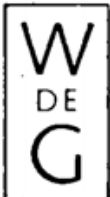

WALTER DE GRUYTER 
(C) The Macmillan Press Ltd, 1988

All rights reserved. No reproduction, copy or transmission of this publication may be made without written permission.

No paragraph of this publication may be reproduced, copied or transmitted save with written permission or in accordance with the provisions of the Copyright Act 1956 (as amended).

Any person who does any unauthorised act in relation to this publication may be liable to criminal prosecution and civil claims for damages.

Published annually since 1864

125th edition first published 1988 by

THE MACMILLAN PRESS LTD

London and Basingstoke and

WALTER DE GRUYTER \& CO.

Berlin

Typeset in Great Britain by

MB GRAPHIC (TYPESETTING) SERVICES

Dunstable, Bedfordshire

Printed in Great Britain by

Richard Clay (The Chaucer Press) Ltd, Bungay, Suffolk

ISBN 3110117428 